\title{
India's Influence on Khotan from the Perspective of Cultural Communication
}

\author{
Liang Yan \\ College of Liberal Arts \\ Tibet University \\ Lhasa, China
}

\begin{abstract}
In the history, the compatibility of India and Khotan in the Western Region in the media and ecological environment has shaped the interpenetrating characteristics of Khotan's ethnic composition, language, military trade and many other factors. Through the interactive influence with India, it finally became a unique Buddhist culture. This paper conducts a tentative analysis and interpretation in the meaning of the Khotan's culture, and restores the true meaning of the Khotan Buddha in a historical context.
\end{abstract}

Keywords-India; Khotan; Buddhism; myth prototype; field

\section{INTRODUCTION}

Buddhism began in India and was introduced to China, which had a radiological influence on the complex cultural circle of China. The heyday of Buddhism in Tang and Sui dynasties was incisive, and it also infiltrated into the neoconfucianism in Song and Ming dynasties and qian-jia learning of simplicity in the Qing dynasty. Up to now, the core layer of the Chinese cultural circle has continued to absorb Buddhist thoughts, and has integrated and derived a broad Buddhist teaching. The Chinese Zen, a wide variety of temple Buddha statues, and mural grottoes fully illustrate the dual influence of Buddhism on the external and internal psychology of Chinese culture. However, among the many Buddhist communication paths, the Buddhist kingdom of the Western Region, which is the secondary transit station of Buddhism, has the reputation of "Minor Western Paradise", Khotan has played a decisive role in the process of Indian acculturation. This not only benefits from the cultural genes in the intrinsic independent variables of an independent cultural element ${ }^{1}$, but also benefits from the synchronicity of many external dependent variables. Regardless of the explicit static cultural representation of the representation or the implicit dynamic field force of the inward, ${ }^{2}$ it is constructed in a three-dimensional manner. The influence of Indian culture on Khotan is deeply rooted in the appearance of the bone marrow. The author attempts to analyze the influence of Buddhism on the dominant and hidden aspects of the Khotan culture from various angles in the history of Indian Buddhism. Thus restore the image of the Buddha Country

From [French] Jacques Derrida, in the "Dissemination" of Dissequence (1972), the factor thought of logocentrism.

From Song Linfei: "Western sociological theory" Nanjing: Nanjing University Press, 1997 static dynamics. before the conversion of the Islamic faith. Khotan and India have had extensive and continuous contacts in history. But there is a question: why in the many countries of the Western Region, Indian Buddhism could become such profound infiltration propagation in the Khotan. After it was introduced, why did it produce such a convergent cultural body in its own viscous cultural structure ${ }^{3}$, and it was highly dynamic and multi-directional ${ }^{4}$ communication and communication with the surrounding.

\section{INFLUENCING FACTORS OF GEOGRAPHICAL ENVIRONMENT AND MYTH GENERATION}

From the geographical point of view, Khotan's Sanskrit name is Ku-stana in the Western Region. "Great Tang Records on the Western Regions" records Khotan's history of the founding of the country, "Han Shu - Western Regions Biography" called it for the name of the Yutian, Yudian, Yudun, Xidan and so on. It is located in the western part of Xinjiang, today's Hetian, and was called the Kustana around the third century AD. The Indians called it Qudan. Since ancient times, it has been the main trade route between India, Persia and China, and it is also a place where Eastern and Western cultures blend. The forty-fifth tome of Generosity and other great classics has the name of Garoshamo. It flanked the Hetian River, with Kunlun Mountain to the south and the Taklimakan Desert to the north. It is the largest oasis in the southern part of the Western Region. It is located on the south side of the Tianshan Mountains and on the south side of the Western Region. It passes west of the Shache and the Panpan to the North India or the cargo. "Historical Records, Dawan Biography", "Han Shu · Western Biography", "Houhan Shu · Western Biography", "Liang Shu · Western Regions", "Wei Shu · Western Biography", and "Sui Shu - Western Biography", have recorded the relationship between Khotan and the surrounding country in the historical literature. The geographical proximity makes it easier for Indian Buddhism culture to reach Khotan in a short period of time. Therefore, Khotan is very advantageous in

\footnotetext{
From Mo Weimin, Jiang Yuhui, Wang Liping, "French Philosophy in the Twentieth Century" Beijing: People's Publishing House, 2008 Merle Ponty Thought.

From Wang Zhihe, editor of the Postmodern Dictionary, Beijing: Central Compilation Press, 2004.
} 
the cohesion, extension ${ }^{5}$ and self-culture construction of religious culture. From the perspective of cultural environment, Khotan is located on an independent node of an organic culture as a whole, with a principled division. Therefore, before the cultural communication, each other will develop abstract, figurative and substantive multi-form cultural characteristics on the basis of self-centered culture. Once the structure is in contact with other different structures, hierarchical interactions and structural interactions are generated. It is precisely in this way that Khotan has completed the promotion of his own cultural organisms, and thus formed a self-effective cultural "tuber" for the further topology and reproduction of culture. ${ }^{6}$

From the mythical prototype, "Great Tang Records on the Western Regions" records that "the king is brave and warlike and advocating Dharma, from the cloud to the descendants of the Shamen. In the past, this country was sparsely populated, and Bishamon once stayed here." ${ }^{7}$ The assistant ministers of the prince of Asoka and the royal family members from the eastern countries jointly established the ancient country. This is the same as the other monk Hui $\mathrm{Li}$ in the Tang Dynasty, who described the legendary expelled person as the prince of Asoka and other plots in his "Daciensi Sanzang master biography". In the "History of pedagogical of Khotan", it is recorded: "In the beginning, the name of the king was called the Diru, the son of the ancient Indian kingdom of Ashoka. Asoka led the soldiers and the entourage to inspect the territory and the folk customs, and arrived at the place where there was a "haizi"... Let the ministers who were exiled by Ashoka and the abandoned prince know each other and get along very well. After the meeting of Diru and Ama Zayashe, they jointly governed their territory and thus established the Khotan city." 8 The tales of legend and "Niujiaoshan Aids" and "Khotan's Award" also appeared in Ashoka many times, and the main story of his plot remains unchanged, with a strong Buddhist color. The Buddhist scriptures of the "Dafa Fangbu" have been called "Rizangjing", which preserves another more Buddhist color for the establishment of $\mathrm{Yu}$. The volume of the "Luoyang Jialanji" volume five and "Khotan" in the "Wei Shu" for the myth of the sacred myths comes from the author's actual collection of Khotan.

It can be analyzed from the above materials that although the authenticity of the mythology itself is open to question, as Roland Barthes said, the myth is to rid the historical

From [French] Jacques Derrida's "Writing and Difference" in 1976, the idea of "extraordinary extension" represents the fundamental characteristics of all differences, including all differences. It exists in all presence, reality and existence, presents its own existence in subverting the existing structure, and together with the dissemination becomes a variant of philosophical implication.

[French] Deleuze, translated by Chen Yongguo: The idea of tuber in "Nomadic Thoughts". Tuber means a complex cultural metaphor and nomadic thinking mode. The tuber leads to an infinitely open and smooth space, and the self forms a heterogeneous energy source.

[Tang Dynasty] Xuan Zang essay, Zhou Guolin translation: "Great Tang Records on the Western Regions" Changsha: Yuelu Press 1999, p. 682.

Li Yinping: "Buddha Khotan", Urumqi, Xinjiang People's Publishing, 1991 edition. p12-p14 quality construction of things by dissolving reality. This kind of construction has some stability, because the myth itself is an extension of reality. ${ }^{9}$ Moreover, Alan Bardot's theory states: "Virtual depends on reality, only different modes of existence, state only." above myths is another real realization process. In this process, we have seen the participation and influence of India in the original state, and this kind of participation and influence itself has many factors attached to Buddhism, which has become one of the factors that influence Buddhism in India. The gods appearing in myths and legends are more or less mixed with Buddhist figures. This similarity in the original configuration makes a stable field of potential communication between India and Khotan, which is one of the necessary conditions for the circulation of Buddhist cultural factors. And as a myth of origin, as Cassirer said in "Mythical Thinking": "The early mythological religious consciousness has not yet demarcated a clear boundary between the field of feeling existence and the field of pure meaning." 11 By organizing the simulation prophets, it was seen the prototype of the origin of Khotan in the mythical meaning of the myth and the connection with India. It is also clear that the essential elements of the hybrid features of mythological thinking is also India, and the possibility of rational isomorphism between the infiltration prototypes can be derived from the logic of hybridity. So the myth itself is Interpretative and intentional. That is to say, from the perspective of mythological morphology and structure, the myth of Khotan's origin is constructed in real elements, and the differentiation of its structure can interpret many connotation factors. ${ }^{12}$

\section{INTERRACIAL AND LINGUISTIC FACTORS}

When the academic circles study the composition of the Khotan race, they usually form the Saka wording, the Qiangren wording, the Rouzhi wording. As far as the Saka wording are concerned, China's "New Tang Book · Western Regions", "Historical Records · Dawan Zhuan", "Han Shu", "Wei Shu · Western Regions" are all described. "Great Tang Records on the Western Regions" and Tibetan "Shouji of Khotan" and "History of pedagogical of Khotan" has a record of the Saka people, which confirms the history of ethnic migration. In the 10th century $\mathrm{BC}$ in the "Mu Tianzi Biography", the Similian tribe in the northern part of the Kunlun Mountains was suspected to be a member of the ancient Saka. Foreign scholars also believe that the residents of Khotan were the survivors of the migration to North India in the 2nd century BC. Stein's information on the investigation of the cricket was later analyzed by British anthropologists: the Khotan people belonged to the West Aryan, and the Aryan nation in the Indian nation was an

\footnotetext{
From the [French] Roland Barthes "Mythology" in semiotics. Editor-in-Chief

10 Chen Yongguo: "The Radical Philosophy Alan Barth Reader" Beijing: Peking University Press, 2010, p. 187.

11 [Germany] Ernst Cassirer: "Mythological Thinking" Beijing: China Social Sciences Press, 1992, p. 250.

12 [United States] George Rizel's "Building Theory in Postmodern
} 
important part of its composition. In addition, Saka, was repeatedly mentioned in two heavyweight epic "Romayanina" and "Maha Bharata" in India. In addition, from the perspective of Rouzhi, "Han - Western Biography", "Historical Records, Dawan Biography", "Northern History" have all described the migration of the Rouzhi, and they all believe that they were driven by the Huns and divided into two. One continued to conquer the Balkh, and one was left in the Khotan area. Wang Guowei also had a detailed study of the migration route of Rouzhi. The Rouzhi people who conquered India established the powerful kushan empire of faith in Buddhism, and the third generation of kings also held the fourth major gathering. In the Dunhuang murals, $\mathrm{Li}$ Shengtian's portrait, also Yuchi Suofupo, and the image of the horse leader in the Song Dynasty's Li Gonglin's "Five Horses" are in good agreement with the appearance of the Rouzhi. It can be seen from this that regardless of whether the historical literature is clear about the Khotan people, the historical expression has already explained that the Khotan people have a commonality with some Indian ethnic groups. Because the two are more likely to spread to each other, it is easy for the two to quickly sew the differences between different cultures. As a result, the Indian Buddhism culture tends to be transmitted to the shackles. Even the sectarian culture and the foreign Buddhism show partial overlap, directly affecting the core layer of the Khotan culture circle. On the other hand, this kind of construction is the basis of a series of subjective hair growth in which cultural regions are intertwined, regional culture is prominent, and culture spread.

Professor Bailey's "Khotan Language Books" elaborated on the close proximity of the language of the Saka to the Indian language and even the Kushan Empire. Pelliot of France thinks that this language is closest to Iranian, so it is called East Iranian, and the Norwegian linguist Stan Konov proves the existence of proverbs through the comparison of the instruments until the German Sanskrit Rüdes' analysis of the letters, the final result is that the proverb is indeed a type of Serbian. As the result of German literary expert En Morrick's analysis from the etymology, we can see that the Saka and the Khotan language, which exist in India, belong to a "basic original" two kinds of differentiation. Khotan was in the early stage of the use of words, such as Wang Shijie: "From the third century BC to the third century AD: there is a language of its own of kharosthi. From the third century to the sixth century AD: early the Saka language in Khotan (belonging to the East Iranian branch) adopts the Brahma alphabet. From the $6^{\text {th }}$ century to the 10 th century AD: later the Saka language in Khotan adopts the Brahma alphabet." 13 kharosthi was the first word popular in ancient northwestern India and was widely used in the Gandhara region. The British linguist Barrow analyzed that the Khotan people used the kharosthi alphabet to spell out their original language. The text of the brahmin was introduced in the battle between the north and the south of the Kushan Empire. The brahmin which flourished in the south, began to attach to the military, trade, and Buddhism, and became an important text that influenced the embarrassment in another period. Moreover,

13 Wang Shijie: "The Edge of the Mysterious Desert" Tianjin: Baihua Literature and Art Publishing House, 2005, p. 62 the new vocabulary and new morphemes are constantly absorbed by the Khotan culture circle, which in turn triggers a variant of the subject language.

Compared to the voices and words in the history of Khotan and India, this complex language system presents an open state. The inextricable links between each other and the foundation of the original language are precisely the favorable conditions for the spread of Buddhist culture. And as the structuralist linguistic school said, the dynamic synchronicity of the two triggered a series of Buddhist cultural effects. If the Khotan language is a system, the Indian language is a system. "According to one proposition, language is a token system; another proposition, language is a social fact." ${ }^{14}$ The language system used as a Buddhist culture itself is a sign of Buddhist culture. Behind this mark is the complex cultural content of the social facts of Indian Buddhism. "In terms of its social role, we must be based on the interrelationship between language and reality beyond the language. Or it has the function of communication, that is, it points out what it means; or it has the function of poetry, that is to say, it points to the token itself." In Indian Buddhism is precisely the reality of language, which is closer to the connection between Khotan and India. The communication function in this connection refers to the language symbol itself borrowed from Buddhist culture. So, "The two languages are very close because they have a common root and lexical basis." ${ }^{16}$ In this case, "The reason why the code is a code is that it can be translated into another code. This is the feature of the code."17 This is one of the important factors that Buddhism flows from India to the Khotan.

\section{MEDICAL COMMUNICATION AND COMMERCIAL CIRCULATION FACTORS}

David A. Utz pointed out: "India's administrative and religious methods, and even to some extent other aspects of Indian culture, such as medicine, constitute the foundation of Khotan's life." ${ }^{18}$ A large number of unearthed documents: "The essence of medical science", Sanskrit and Khotan language bilingual "Qipo Book" and "Khotan Literature Guide" show that India and Khotan are closely related to each other. On the other hand, bilingual and two-way communication affected the bilingual translation and input and output of later Buddhist scriptures. For example, Sanskrit is written in the essay "Golden Light Sutra", numbered P. 2899. On the front, the book "Xvmoti Zhangzhe

\footnotetext{
14 Louis-Jean Calve: "Pour et countre Sauaature", Payot, pp. 82-83, 1975.

15 [French] Francois Doss, Ji Guangmao translated "From the structure to the deconstruction of the main trend of French 20th century thought" Central Compilation Press, 2009, p. 76.

16 [French] Francois Doss, Ji Guangmao translated "From the structure to the deconstruction of the main trend of French 20th century thought" Central Compilation Press, 2009, p. 76.

$17 \quad$ Fanshang Dekongbu: "Le Meme et lautre" Minuit, 1979, p. 121.

18 David A. Utz, Khotan: Indian Urbanization, Historical Tradition and Nomadic Culture, (unpublished paper) p.5. quoted from Victor H. Mair, The Khotanese Antecedents of The Sutra of the Wise and the Foolish(Xian yu jing in Erik Zǜrcher. et al..eds..Buddhism across Boundaries, Chinese Buddhism and the Western Regions, pp.416-418.
} 
Sutra" is written at the beginning of "All sutra in Khotan Kaiyuan temple, and the book is backed up in the Khotan language medical literature". ${ }^{19}$ The Tantra of traditional Chinese medicine is complex, such as the Thousand Eyes of the Dharani, the Guanyin Dharani, and the Shanmen Dharani. It is known that the first is the introduction and prosperity of Indian esotericism; the second is the penetration of Indian medicine into sputum medicine and the close integration of the two; the third is to spread the secret law to the Han Dynasty in the Central Plains and to integrate with the Tibetan Tantrics laying the common context and the same potential field.

Search on the commercial traffic route. Li Yinping's research on the traffic roads of the Khotan in his "Hetian history traffic route research" shows that Kotan's history has focused on the construction of traffic roads, and the transportation facilities such as the station are complete, and due to the special environment of the desert area, traffic routes generally converge with the river course, which is more conducive to merchants from the water source. Therefore, the three main roads leading to the outside along the river channel have special significance in the spread of Indian Buddhism. Khotan, what is known as the silk pipa and the country of the jade, Khotan's document number P. 2741, "Shazhou Shangdu Jinzouyuan Shangbenshi Zhuang", P.3547, and many other documents are related to jade production, jade processing, and jade circulation. The prosperous Khotan used its economic advantages to form a well-equipped trade market in the history of East-West exchanges, and a large number of Chinese and foreign coins discovered by archaeological studies also proved this to some extent. "Han-kharosthi two-body money" not only proves the prosperity of the business, but also the two fonts are on the same coin, but also the confirmation of the commercial exchange between India and Khotan. As Wang Shijie concluded, one of the ways in which Indian culture was introduced into the Khotan was through business travel. We have reason to believe that Buddhist culture is introduced to Khotan by commercial activities or by means of convenient transportation. Moreover, during the period of the Kushan Empire, a group of wealthy merchants of the Kushan Empire moved to Khotan. In a certain sense, it promotes the exchange of culture.

\section{INDIA'S EXPANSION AND THE EMPEROR FACTORS}

In the history of India's full importation of Buddhist culture, two emperors were particularly keen. One is the Ashoka period, and the other is the period of the Kushan Empire. During the Ashoka period, the strength of national power and the great reunification of India gave Buddhism an unprecedented prosperity. The "Introduction to the History of Indian Buddhism" by Sasaki of Japan describes that Ashoka practiced Buddhism, carried out teachings of Buddhism to the people, and adopted a tolerant attitude toward all religions. In order to clean up the Sangha chaos, a third compilation of Buddhist scriptures was carried out,

19 H. W. Bailey, ed., Khotanese Texts, III, Cambridge: Cambridge University Press, 1969, p. 78. called the third assembly after the annihilation. This collection is described in "The History of Indian Buddhism" by A.K. Warder, "The History of Indian Buddhism" written by British Warder, and Zhang Mantao's "Modern Buddhist Academic Series 93, The First Series of Three Indian Buddhist History (Part 2 of the Indian Buddhist Collection)", the book "The History of Indian Buddhism" edited by Huiyuan recluse, and the "Basic Knowledge of Buddhism in Buddhism" written by Master Sheng Yan. It can be seen from this that the strength of military power has made Asoka's sphere of influence expand widely. Taranatha's "History of Indian Buddhism" has already reached the Khotan area, and there are also Tibetan and Chinese materials description Khotan's establishment, that in a certain sense, establishes the possibility of Buddhism spread between the two countries. Moreover, the third assembly of Ashoka was to some extent an enhancement of the internal forces of the source of Indian Buddhism, and he sent teachers to pass the Buddhism. Although it is not explicitly mentioned in Khotan, there is reason to believe that this wave of Buddhism transmission must have spread to the Khotan area. Before and after the fourth gathering in the Kushan Empire, the Buddhism was divided into two major schools: Mahayana and Hinayana. The king of Kaniska was worshipped by Mahayana Buddhism. Due to the vigorous promotion of the Kushan Empire, Mahayana Buddhism gradually emerged and Buddhism entered its heyday. At this time, the Madhyamika created by the Indian nagarjuna and the deva appeared, that was the original faction of Mahayana Buddhism. The Madhyamika spread widely in ancient India and spread far outside the territory, affecting Central Asia and East Asia. Khotan, who originally believed in the Hinayana Buddhism, began to extensively contact and convert to Mahayana Buddhism. Based on the factors of the Rouzhi race and the wealthy merchants of the Kushan Empire, Khotan accepted Indian Buddhism during this period. This provides a strong energy support for the continued development of this Buddhist transfer station.

In "Song Yun Xing Ji", it was recorded that in the past, Kings of the Khotan did not believe in Buddhism. The merchant introduced a monk to the king, who was the disciple of Buddhism. Under a tree of apricot trees, Vairocana showed the true meaning of the Buddha for the king, and the king of Khotan began to believe in Dharma. There is a similar narrative in "Great Tang Records on the Western Regions" and Tibetan literature "History of pedagogical of Khotan". From the history of Khotan, the Yuchi family, who ruled for a long time, tried their best to support Buddhism. The Tibetan document "Khotan's Fashou Inscription" is recorded in the king of Khotan, called Vijaya Sambha-va. The religious name $\mathrm{Pu}$ Shengsheng is the incarnation of Maitreya Bodhisattva, and the Vairocana is the incarnation of Manjushri. In his paper "Research on Khotan", Norwegian scholar Sten Konow believes that Hugh Moba is the transliteration of Sambhava, whose full name is Vi-jaya Sambhava, the first to introduce Buddhism. In the history, many royal families not only issued orders to protect monks, but also dispatched envoys to the outside world. As a state religion of Buddhism, Khotan's rituals of worshiping Buddhas are quite spectacular. According to the description 
of Faxian, Khotan began to clean the streets on April 1 every year. The gates of the city were hoisted. The kings and nobles of the whole city worshipped the country and worshipped the Buddha statues loaded by four-wheeled vehicles in fourteen days in a row." ${ }^{20}$ As can be seen from the above activities, Buddhism is actually a state religion in Khotan, a major Buddhist activity, spending a lot of money and manpower, and the king became the leader of these activities." A splendid temple near capital, due to the smashing of the king, took 80 years to go through three generations of kings and all the national strength. It is obvious that the royal family respects Buddhism. Khotan, which was the recipient of Indian Buddhism, had the following remarkable results in the further development of Buddhism in the case of the royal family so revered buddhist.

\section{A. The Emergence of the Translating Mission of Monks and the Active Teaching of Eminent Monk}

"In addition, Zhu Shixing entered the Western Region in the Northern Wei Dynasty, Ganlu five years, and passed the Khotan. He got the Astasahashrika prajna paramita Sutra, and let the disciples return to Luoyang. Zhu Shixing first let two people Wu Luoyi and Zhu Shulan translate the Radiate the prajna sutra. This is the first time for Chinese people went to the Western Regions to seek Buddhism." ${ }^{21}$ Zhu Shixing's first study and translation is of great significance. "In the early 5th century, it was at the height of Buddhism in the Khotan Kingdom. There were fourteen big Buddhist Temple in the middle of the country. There were countless small temples and there were tens of thousands of monks. Most of them learned Mahayana Buddhism."22 Among them, the most famous translation monk Siksananda was twice translated by the Central Plains Dynasty, of which means "learning happy". "Eminent Monks Biography" said that he "recovers his wisdom, does not have a good style, and is good at multiplying and subsistence." It is obvious that he is an outstanding scholar. He has brought a large number of classics from the Khotan to the Central Plains and translated them. In addition, there is Samana devanprajna, he learns to pass the Mahayana and Hinayana, wisdom and truth, and the Zen Temple is known, and there are many translations. Khotan's loose legal environment has made the eminent monks of Central Plains, India, and Tibet arrived. For example, the First person to fetch scripture of Central Plains, Zhu Shixing and Fa Xian, Xuanzang and so on. For example, the East tianzhu sanzang samana samana Dharma zen returned to the country from the Central Plains to the West, because of the disease in the way, from Kashgar to Khotan, lived in the Jinlun and died in this temple. After the middle of the 8th century, Tibet sent a large number of young people to study the Buddhist scriptures and retrieve them from the classics of Khotan. According to Tibetan historical records,

20 Li Yinping: "Hetian Chunqiu", Urumqi, Xinjiang People's Publishing House, 2006 edition, p59.

21 Zhang Mantao edited, "Modern Buddhist Academic Series 92, first series of volume 2 Indian Buddhist Overview", the first edition of 1979.

22 Zhou Liankuan: "Research on the Kustana", collected in his book "Compilation of historical and geographical studies on Great Tang Records on the Western Regions", Zhonghua Book Company, 1984, p229-p236. "mkas-pavi-dgav-ston", "Tibetan King of the Dynasties", "Qing Shi" and other books, Songtsan Gambo has invited a group of people from the Central Plains, Tubo, Khotan and other monks to translate the classics from the Central Plains of Chinese and Khotan language. Khotan actually became a huge translation field, making an invaluable contribution to the Buddhist scriptures passed from India.

\section{B. A Large Number of Buddhist Scriptures' Apperance in Khotan}

It was the first stop for Indian Buddhism to enter China. The original Mahayana Buddhism classics translated by Chinese translators originally came from Khotan. For example, Zhu Shixing in Wei Dynasty went west to seek the original "Radiate the prajna sutra", which is from Khotan. In the Xijin Dynasty, the Zhi Faling got thirty-six thousand sanskrit versions of the gatha sutra. The classics of the meditation of Ju Qu's translation of the chanting method are mostly from Khotan. In Qi Dynasty, Dhammazedi translated "Saddharmapundarika Sutra · timadapine", although only one volume, but the earliest interpretation of "Saddharmapundarika Sutra" was originally derived from the Khotan. At that time, there were six thousand and five hundred verses of "Saddharmapundarika Sutra" in the royal palace of the Khotan, and there were forty volumes of the "Mahaparinibbana Sutta", only the first twelve volumes were originally brought from India, and the rest were obtained in Khotan, which is not just a simple translation of Buddhist scriptures. At the end of the 19th century, Khotan's "Ysambas L6-z8m basta" and "Buddha Himself" were all written in the original scriptures of Khotan language. The Russian consul Peterovsky and the French Dutreyi and others purchased the "Dharmapada" in kharosthi as hinayana classic, and to a certain extent also explained Khotan's contribution to the spread of the hinayana buddhism.

\section{Temples and Buddhist Art}

The Tibetan literature "rgya bod yig tshang" records: "In general, there are 68 temples in and outside the Khotan's city, and there are 95 temples in the middle of the temple and 148 in the temples. In addition, in the small temples in the wild and the Buddhist temples that are not temples, there are 3,680. According to statistics, Khotan has a total of 10,000 monks." ${ }^{23}$ Zhang Guangda, Rong Xinjiang had a detailed examination of the main monasteries in the history of the temple was carried out in the article "Khotan Buddhist Temple". The temples were the Zanmo Temple, the Gomati Temple, the Niutou Mountain Temple, the Wangxin Temple, the Vishama temple, the Mashe Temple, the Longxing Temple, the Dro-tir Temple, the Temple of Pure Land, the Temple of Deva vona, and the Huguo Temple, Jinlun Temple, Sakya Yellen Temple, Bhima Temple. The book "Khotan's vyakarana", which is specially recorded in the case of the Buddhist Temple, also lists a large number of monks and nuns such as Maitreya Temple, Jiashini Temple, and Princess Temple. In the "Buddha Kingdom", the

23 Dacang Zongba - Banjue Sangbu: The Collection of Han and Tibetan History, translated by Chen Qingying, Tibet People's Publishing House, 1986, pp. 53-59. 
architectural structure of Khotan's Wangxin Temple is welldecorated. Khotan, a small country with a small project, has so many temples. It can be seen that the practical influence of the Indian Dharma on the physical communication has been quite large. In addition to the archaeological discovery of the ruins of the temple, a large number of Buddhist works also fully demonstrate the true face of Buddhism in Khotan. At the beginning of the 20th century, Stein excavated a large number of statues of Buddha statues, colored murals, Buddhist prints and ninety-one giant Buddha statues that shocked the world near Rawak. From the perspective of plastic art, the Buddha statue has an obvious Indian Gandhara style, which just confirms the influence of the Gupta Dynasty of the Indian Buddhism in the golden age on Khotan.

\section{Further Spread of Culture}

During the Tibetan rule, Manuscripts wrote in Khotan of the number MT.bii.0065 recorded: "Since the best Tibetans guarded the country, its rule has entered its sixth year." Khotan's Buddhism also incorporates Tibetan Buddhism, its domestic Zanmo temple evolved into the tantric base of the Western Region. The German scholar Klinkett researched and pointed out: "The most outstanding paintings of Khotan, mostly produced in the 6th-8th century AD... these patterns, such as the double-headed vajra, some of them have the characteristics of tantrism. It is definitely a tantric, a threeheaded god that is probably regarded as mahakala," 24 Professor Huo Wei wrote: "The most representative is Khotan. The records of the introduction of early Buddhism in this place are mostly myths and legends, which are very similar to the situation in Tibetan." 25 This shows biblical figures that between Khotan and Tibetan. From the geographical transportation, Moriyasu Takao believes that there are two paths from the central Tibet (the birthplace of the Tibetan Kingdom) to the Karakorum and Pamir routes in the northwest; the other is the route from the northeast of Tibet to Qinghai and Qaidam. ${ }^{26}$ The scholar Huo Wei has verified the other two by the literature method, one is the Bolvdao Road; the other is the Tibetan's Five Avenue, this road is to Yangtong. According to "Shiying Fangzhi" recorded: "The great Yangtong is next to the Tibetan in the east, the Sanboke in the west, and the Khotan in the north."27 The opening of the middle road is more convenient to connect the traffic between Khotan and Tibetan. Professor Huo Wei further used the mutual verification method of archaeology and literature to obtain the transportation route of Tibet-Khotan-India. This proves to some extent that Khotan's unique geographical location in communicating the

24 [German] Klinkett, translated by Zhao Chongmin: "Culture on the Silk Road", Xinjiang: Xinjiang Fine Arts Photography Press, 1994, p158-p159.

25 Huo Wei: "From the archaeological materials, the discussion on ancient traffic of Tibet and Central Asia, West Asia - and the historical position of the western Tibet in the process of Buddhism's introduction to Tibet" Beijing: China Tibetology, No. 4, 1995, p. 50.

26 [Japan]Moriyasu Takao: "Tibet in the history of central Asia-Prospect of Tibet's position in world history", translated by Zhong Meizhu, "Tibetan Research", No. 4, 1987, p. 111.

27 Section Four in Relics Part of Volume one of "Shiying Fangzhi".
Tibet and India and also illustrates the mutual infiltration of the three cultural fields and types in the historical and spatial dimensions.

\section{CONCLUSION}

In summary, the author believes that as the "Western Paradise" of India and as the "minor Western Paradise" of Khotan, there is a lot of communication and integration between the two because of the cultural medium of Buddhism. As the source of communication, in addition to the military expansion of the powerful empire and emperors in history, and the belief in the Dharma and its active implementation, the geographical advantages and ethnic affinities of the two countries have also been the key factor making the Buddhist culture in-depth exchanges. As a recipient of Khotan, the active construction of the traffic, the dying of the Dharma in the past, and the Buddhist monks who have produced talents all constitute the prosperity of the Dharma. In particular, although Khotan has become a transit point for Buddhist culture, it can be seen from another angle that Khotan's secondary source of communication has become the source of Buddhist subject communication. It played a major role in spreading Tibet and especially in the Central Plains and even further Japan, and produced a fissile effect.

\section{REFERENCES}

[1] Ji Xianlin. "The History of Cultural Exchange between China and India", Beijing, China Social Sciences Press, 2008 edition. (in Chinese)

[2] Wang Rong: "Kunlun Misty — Khotan", Kunming, Yunnan People's Publishing House, 2002 edition. (in Chinese)

[3] Zhang Guangda, Rong Xinjiang. "Collected Essays of Khotan's History", Beijing, China Renmin University Press, 2008 edition. (in Chinese)

[4] Li Yinping. "Hetian Chunqiu", Urumqi, Xinjiang People's Publishing House, 2006 edition. (in Chinese)

[5] Li Yinping. "Archaeological Records of Khotan", Urumqi, Xinjiang People's Publishing House, 2006 edition. (in Chinese)

[6] Li Yinping. "Buddha Khotan", Urumqi, Xinjiang People's Publishing, 1991 edition. (in Chinese)

[7] Ma Dazheng. "Speculum Historiale of Xinjiang", Urumqi, Xinjiang People's Publishing House, 2006 edition. (in Chinese)

[8] Yu Taishan, editor: "the Western History", Zhengzhou, Zhongzhou Ancient Books Publishing House, 1996 edition. (in Chinese)

[9] Ji Xianlin. "Today's Translation of Great Tang Records on the Western Regions", Xi'an, Shaanxi People's Publishing House, 1985 edition. (in Chinese)

[10] (British) Stein. "Stein Westland Archaeology", Beijing, Zhonghua Book Company, the 35 th edition of the Republic of China. 